\title{
Expression of PER, CRY, and TIM genes for the pathological features of colorectal cancer patients [Retraction]
}

Wang Y, Cheng YS, Yu G, et al. Expression of PER, CRY, and TIM genes for the pathological features of colorectal cancer patients. OncoTargets and Therapy. 2016;9:1997-2005.

Concerns about this paper were raised by a reader. Upon seeking an explanation from the authors we conclude that the content and data in the paper were extensively plagiarized from:
Mazzocoli G, Panza A, Valvano MR, et al. Clock Gene Expression Levels and Relationship with Clinical and Pathological Features in Colorectal Cancer Patients. Chronobiology International. 2011;28(10):841-851.

Dr Faris Farassati has decided that the paper in OncoTargets and Therapy should be retracted, and the relevant supervisors at the authors institutions are advised of this decision.

\section{Publish your work in this journal}

OncoTargets and Therapy is an international, peer-reviewed, open access journal focusing on the pathological basis of all cancers, potential targets for therapy and treatment protocols employed to improve the management of cancer patients. The journal also focuses on the impact of management programs and new therapeutic agents and protocols on

\section{Dovepress}

patient perspectives such as quality of life, adherence and satisfaction. The manuscript management system is completely online and includes a very quick and fair peer-review system, which is all easy to use. Visit http://www.dovepress.com/testimonials.php to read real quotes from published authors. 